\title{
PERBEDAAN PERAWATAN TALI PUSAT MENGGUNAKAN KASSA TOPIKAL ASI DENGAN KASSA KERING TERHADAP LAMA WAKTU PELEPASAN TALI PUSAT
}

\author{
Masjidah, $\mathrm{SA}^{1}$, Mualimah $\mathrm{M}^{2}$, Riska $\mathrm{H}^{3}$ \\ ${ }^{1}$ Program Studi Diploma IV Kebidanan, Universitas Kediri, Indonesia \\ ${ }^{2}$ Program Studi Diploma IV Kebidanan, Universitas Kediri, Indonesia \\ ${ }^{3}$ Program Studi Pendidikan Profesi Bidan, Universitas Respati Yogyakarta, Indonesia
}

\begin{abstract}
Good cord care is an effort to prevent neonatal infection. There are various method of treatment used such a steril gauze, alcohol gauze 70\%, povidone iodine (Betadine) 10\%, and traditional treatments using honey, ghee oil (India), and breast milk. This study aims to find the difference umbilical cord treatments using breast milk topikal gauze and steril gauze in released times of cord in BPM NY"A" Sidoarjo. This was an experimental study with quASI experimental design. The population in this study was infants born during May until Juli at BPM NY"A", as many as 20 respondents that comprised by 10 respondents with breast milk topical gauze and 10 respondents with an sterile gauze. The data sampling used puposive sampling technique by observation. The normality test used Shapiro-Wilk test and the statistical analyses used Mann Whitney test. The results of this study indicate that the longest of release time of infant's umbilical cord which wrapped by using an breast milk topikal indicate that the fastest release time is less than 5 days as many as 5 respondents (50\%) and the normal release time (5-7 days) as many as 5 respondents (50\%). The results of study by a sterile gauze is more than 7 days as many as 4 respondents (40\%) and the normal released time (5-7 days) as many as respondents (60\%). There is a difference between the release time between umbilical cord which wrapped by using sterile gauze and by having breast milk topical with $p$ value of 0.003 . The mothers of the respondents are suggested to choose open treatment as an effective treatment. For further researchers are expected to make direct observation to the other influencing faktors of the release time of the umbilical cord.
\end{abstract}

Keywords : Breast Milk Topica; Sterile Gauze; Release Time Of Umbilical Cord 


\section{PENDAHULUAN}

Asuhan kebidanan pada bayi baru lahir perlu mendapatkan perhatian khusus. Beberapa tindakan yang kurang tepat dapat berakibat fatal bagi bayi baik secara langsung maupun tidak langsung. Daerah yang memerlukan perhatian adalah luka pemotongan talipusat. Karena merupakan tempat uatama terjadinya kasus tetanus neonatorum serta faktor kehilangan suhu sangat perlu diperhatikan pada saat bayi baru lahir.(Tando, 2013)

Perawatan tali pusat dapat dilakukan secara terbuka maupun tertutup. tujuan utama dari perawatan tali pusat adalah mencegah terjadinya infeksi pada tali pusat. infeksi pada tali pusat sebagai faktor penyebab kematian pada bayi. Kematian neonatus dapat disebabkan oleh tetanus neonatorum (Rosita, 2016)

Kejadian kematian karena tetanus pada bayi di Indonesia berkurang seiring dengan kemajuan teknologi dan peningkatan pengetahuan dan ketrampilan tenaga pemberi asuhan kebidanan pada bayi baru lahir. Jumlah kasus meninggal karena tetanus neonatorum mengalami penurunan jumlah terutama yang terjadi pada neonates usia sebelum 7 hari. (Tantijati and Bantas, 2006)

Hasil penelitian Sari tahun 2016 tentang perawatan tali pusat lebih ekonomis pada praktis dengan menggunakan kasa steril dibandingkan dengan menggunakan kasa alcohol dan povidone iodine walaupun untuk waktu lepasnya tali pusat tetap bervariASI. (Yunanto, Hartoyo and Budiarti, 2016)

Perawatan tali pusat dapat dilakukan secara mandiri oleh ibu dan keluarga dengan menerapkan prinsip aseptic dan antiseptic agar bayi terhindar dari infeksi. Kasih sayang ibu dalam merawat dan memperhatikan kebutuhan bayinya akan meningkatkan kesejahteraan bayi (Ramadhani and Astutiningrum, 2019)

Alternatif merawat tali pusat selain menggunakan kasa kering dapat juga dengan mengunakan ASI sebagai zat anti septic yang dapat dipilih ibu secara tradisional. Kandungan zat anti body anti alergi dan antiseptic dalam ASI dapat memberikan pengaruh dapalam merawat tali pusat. selain hygienis dan praktis metode ini juga sangat ekonomis dan bisa dilakukan ibu secara mandiri kepada bayinya Pemberian ASI secara topikal pada tali pusat dapat digunakan sebagai cara yang mudah, murah dan tidak invasif untuk perawatan tali pusat hanya dengan meneteskan ASI pada bagian sisa tali pusat. (Supriyanik and Handayani, 2012). Berdasarkan data tersebut, peneliti bermaksud melakukan penelitian dengan tujuan untuk mengetahui perbedaan perawatan tali pusat menggunakan kasa topikal ASI dengan kasa kering terhadap lama waktu lepasnya tali pusat di BPM Ny "A" Sidoarjo 


\section{METODOLOGI PENELITIAN}

Metode penelitian ini adalah pre eksperimen. dengan Populasi adalah seluruh bayi baru lahir pada bulan Mei - Juli 2017 di BPM NY " A" Sidoarjo yang berjumlah 20 bayi. Sampel dalam penelitian ini terdiri dari 10 orang bayi yang mendapat perawatan tali pusatnya menggunakan kasa topikal ASI dan 10 orang bayi dan perawatan menggunakan kasa steril. Instrumen yang digunakan dalam penelitian ini adalah lembar observasi digunakan untuk mengumpulkan data dengan mengamati dan mengetahui kepatuhan mengikuti anjuran Teknik sampling yang digunakan dalam penelitian ini adalah Purposive Sampling. Uji statistik Wilcoxon Match Pair Test yaitu untuk menguji hipotesis komparatif

\section{HASIL PENELITIAN DAN BAHASAN}

Hasil penelitian lama waktu lepas tali pusat menggunkan kasa topikal ASI menunjukkan bahwa setengah dari bayi yang menggunakan kasa topikal ASI, tali pusat lepas dalam waktu kategori lambat ( hari ke 7) sebanyak 3 bayi, hari ke 6 sebanyak 2 bayi, dan hari ke 4 hari sebanyak 5 bayi . Tali pusat pada waktu secara umum (5-7 hari) sebanyak 5 bayi dan cepat (< 5 hari) sebanyak 5 bayi Pada perawatan tali pusat dengan menggunakan kasa topikal ASI tali pusat umumnya lepas lebih lama, hal ini dipengaruhi oleh beberapa faktor yaitu faktor dari keadaan dan kelembapan tali pusat. tingkat kepatuhan ibu untuk melakukan perawatan tali pusat pada bayinya. Kondisi tali pusat yang perlu diperhatikan bila kondisi masih basah atau terlihat kotor. Faktor lainnya adalah frekuensi ibu melakukan perawatan tali pusat dalam sehari. Faktor sekitar bayi adalah penggunaan diapers perlu diperhatikan tingkat lembab sekitar tali pusat. Metode perawatan dengan menggunakan ASI masih jarang digunakan sehingga perlu memberikan pengetahuan dan terus mendampingi ibu dalam melakukan tindakan perawatan tali pusat. Teknik yang perlu diajarkan kepada ibu adalah saat mengoleskan ASI di daerah pangkal tali pusat dengan cotton bud serta selalu menjaga kebersihan agar tetap kering. Keuntungan penggunaan ASI dalam merawat tali pusat adalah terkandung SigA (secretory igA sebagai zat antibodi berfungsi untuk dapat melindungi permukaan organ tubuh terutama bekas pemotongan tali pusat agar terhindar dari bakteri dan virus yang berbahaya.( Laksawati,2009). 
Tabel 1.Tabulasi antara perbedaan lepasnya tali pusat berdasarkan jenis perawatan.

\begin{tabular}{lllllll}
\hline Variabel & Perawatan & $\mathrm{n}$ & Mean & SD & Z & P-Value \\
\hline Waktu lepas & Kasa Topikal ASI & 10 & 1.50 & 0,527 & \multirow{2}{*}{2,936} & 0,003 \\
& Kasa kering & 10 & 2.40 & 0,516 & & \\
\hline
\end{tabular}

Sumber : Data Primer Penelitian, Juli 2017

Berdasarkan tabel 1 dapat diketahui bahwa rata-rata waktu lepas tali pusat bayi yang dibungkus dengan kasa steril adalah 2,40 hari, sedangkan rata-rata waktu lepas tali pusat bayi yang dirawat dengan kasa topikal ASI lebih cepat yaitu 1,50 hari.

Analisa uji statistik dengan Uji Mann Whiteny didapat $p$-value 0,003 . $p$-value $=$ $0,003<(0,05)$, sehingga $\mathrm{H} 0$ ditolak dan $\mathrm{H} 1$ diterima, ada perbedaan yang signifikan waktu lama lepasnya tali pusat yang di rawat kasa topikal ASI dengan kasa steril pada bayi di BPM NY"A" Sidoarjo.

Hasil analisa dari uji statistik dengan Mann Whiteny antara waktu lepasnya tali pusat pada perawatan menggunakan kasa topikal ASI dengan kasa steril terhadap lama waktu pelepasan tali pusat besarnya nilai $Z=-2,936$ dan $p \quad 0,003$ tingkat kepercayaan $95 \% \quad(\alpha \quad(0,05) \quad$ yang dikatakan $\mathrm{p}$ value $<\alpha$ yang berarti $\mathrm{HO}$ ditolak dan $\mathrm{H} 1$ diterima, artinya ada perbedaan perawatan tali pusat menggunakan kasa topikal ASI dengan kasa kering terhadap lama waktu lepas tali pusat di BPM NY "A" Sidoarjo.

Perawatan tali pusat menggunakan kasa steril cukup efektif namun tidak secepat perawatan tali pusat kasa topikal ASI,

karena perawatan hanya dengan menggunakan kasa bersih tidak mengandung zat-zat tertentu sehingga tidak dapat membantu proses lepasnya tali pusat seperti halnya topical ASI.

Hasil penelitian Wulandini tahun 2018 menyatakan bahwa pengetahuan ibu tentang perawatan tali pusat akan mempengaruhi praktik dalam memberikan perawatan tali pusat yang benar agar terhindar dari tetanus neonatorum (Wulandini and Roza, 2018)

Hasil penelitian Supriyanik 2018 didapatkan bahwa dengan perawatan talipusat menggunakan ASI sebagai bahan antisepstik topical akan mempercepat proses pelepasan tali pusat rata - rata pada hari ke 4 dibandingkan yang hanya dengan kasa kering terjadi pada hari ke 6 dengan selisih sekitar 2 hari memberikan kemungkinan bayi terhindar dari tetanus neonatorum lebih besar (Supriyanik and Handayani, 2012)

\section{KESIMPULAN}

Terdapat perbedaan perawatan tali pusat menggunakan topikal ASI dan kasa steril dengan lama waktu pelepasan tali pusat Sebagai masukan memberikan informasi yang tepat dan lengkap mengenai perbedaan perawatan tali pusat 
menggunakan kasa topikal ASI dengan kasa steril terhadap lama waktu pelepasan tali pusat di BPM. NY "A" Sidoarjo. Penelitian selanjutnya dapat dilaksanakan dengan jumlah sampel serta metode intervensi lain yang dapat mencegah tetanus neonatorum.

\section{Ucapan Terimakasih}

Terima kasih saya ucapkan kepada seluruh pimpinan Universitas Kadiri dan Universitas Respati Yogyakarta yang telah mendukung penelitian dan publikasi ini.

\section{DAFTAR PUSTAKA}

1. Ramadhani, F. P. And Astutiningrum, D. (2019) 'Asuhan Keperawatan Pasien Post Partum Spontan Dengan Masalah Keperawatan Defisiensi Pengetahuan Tentang Perawatan Tali Pusat Pada Bayi Baru Lahir Di Rsud Dr. Soedirman Kebumen', Proceeding Of The Urecol.

2. Rosita, N. A. (2016) 'Hubungan Paritas Dengan Perawatan Tali Pusat Pada Bayi Baru Lahir Oleh Ibu Postpartum Di Klinik Bersalin Hj. S. Tarigan Di Kota Pangkalpinang', Jurnal Kesehatan. Doi: 10.26630/Jk.V7i2.204.

3. Supriyanik, F. And Handayani, S. (2012) 'Perbedaan Perawatan Tali Pusat Dengan Menggunakan Asi Dan Dengan Kassa Kering Terhadap Lama Pelepasan Tali Pusat Bayi Baru Lahir Di Bps Endang Purwati Yogyakarta', Jurnal Kesehatan Samodra IImu.

4. Tando (2013) Asuhan Kebidanan Persalinan Dan Bayi Baru Lahir, In Media. Doi: 10.1192/Bjp.111.479.1009-A.

5. Tantijati, L. And Bantas, K. (2006) 'Faktor-Faktor Prognosis Kematian Tetanus Neonatorum Di Rs Kabupaten Indramayu Dan Kabupaten Cirebon', Kesmas:
National Public Health Journal. Doi: 10.21109/Kesmas.V1i2.311.

6. Wulandini, P. And Roza, A. (2018) 'Pengetahuan Ibu Tentang Perawatan Tali Pusat Di Posyandu Kasih lbu Desa Penghidupan Kampar Riau 2018', Journal Of Midwifery Science) P-Issn.

7. Yunanto, A., Hartoyo, E. And Budiarti, L. Y. (2016) 'Peran Alkohol 70\%, Povidon-lodine 10\% Dan Kasa Kering Steril Dalam Pencegahan Infeksi Pada Perawatan Tali Pusat', Sari Pediatri. DOI: 10.14238/Sp7.2.2005.58-62. 